\title{
Low prevalence of antibiotic-resistant gram-negative bacteria isolated from rural south-western Ugandan groundwater
}

\author{
Olusegun O Soge ${ }^{1}$, Michael A Giardino', Iana C Ivanova', Amber L Pearson², John S Meschke ${ }^{1}$ \\ and Marilyn C Roberts ${ }^{1 *}$ \\ ${ }^{1}$ Department of Environmental \& Occupational Health Sciences, Box 357234, School of Public Health, \\ University of Washington, Seattle, WA 98195-7234 \\ ${ }^{2}$ Departments of Geography \& Global Health, University of Washington, Seattle, WA 98195
}

\begin{abstract}
The objective of this study was to determine antibiotic resistance patterns and specific resistance genes in Gram-negative enteric bacteria recovered from 42 different drinking water sources servicing 2 rural villages in south-western Uganda. These water sites were prone to contamination by both human and cattle activity. Of the 52 isolates examined, 26 carried antibiotic resistance genes with 25 being ampicillin resistant, 21 carrying the $b l a_{\text {TEM }}$ gene, and no isolate carrying genes coding for extended-spectrum $\beta$-lactamases. Twelve isolates were tetracycline resistant and these bacteria carried between 1 and 3 different tet genes, with the tet(A) gene the most common. Six isolates carried the macrolide resistance mef(A) and/ or the macrolide-lincosamide-streptogramin B resistance erm(B) genes. Four isolates carried the sull gene, and 4 isolates carried the sull and int 1 genes indicating the presence of Class 1 integrons. The Ugandan isolates in this study had lower than expected carriage rates of antibiotic and multi-drug resistance genes, carriage of Class 1 integrons and lacked genes coding for extended-spectrum $\beta$-lactamases as compared to antibiotic resistance carriage in clinical African isolates.
\end{abstract}

Keywords: drinking water, antibiotic resistance, resistance genes, Gram-negative, conjugal transfer

\section{Introduction}

Pearson et al. (2008) reported on the isolation and biochemical characterisation of water-borne Gram-negative bacteria isolated from boreholes, ponds and valley water tanks used by 2 rural villages, from Nyabushozi County in the Mbarara District of south-western Uganda. Both humans and animals used the water sources and the $E$. coli counts confirmed that 38 of the 42 water sites did not meet international drinking water standards. The inhabitants of these villages were settled and seminomadic Bahima pastoralists, Bairu agriculturalists and a few internal migrants. The villages had undergone dramatic water resource changes as a result of land privatisation and the creation of a national park in 1989. The villagers were 10 to $15 \mathrm{~km}$ from the nearest local private medical clinic, which charged money for its services and 40 to $50 \mathrm{~km}$ from the nearest hospital. These communities lacked the infrastructure required for basic services, such as health care and a municipal drinking water supply. As a result, these people had little interaction with western medicine and relied on traditional herbal treatments for human and livestock diseases (authors' unpublished observations).

The currently published literature suggests that levels of antibiotic-resistant bacteria are high and continue to rise in Africa (Okeke et al., 2007). There are no data on antimicrobial susceptibilities of water bacteria from Uganda. Therefore it was of interest to characterise the level of antibiotic resistance and corresponding resistance genes in the Ugandan bac-

\footnotetext{
* To whom all correspondence should be addressed.

풀 206-543-8001; fax: 206-543-3873; e-mail: marilynr@u.washington.edu

Received 13 January 2009; accepted in revised form 20 February 2009.
}

teria previously isolated from 42 of the 47 Ugandan water sites tested which serviced the 2 villages. In this study, the antibiotic resistance phenotypes and genotypes of 52 randomly selected Gram-negative enteric bacteria from Nyabushozi County in the Mbarara District of south-western Uganda were characterised.

\section{Materials and methods}

\section{Bacterial isolates}

Previously, water-borne Gram-negative bacteria were recovered from $1 \mathrm{~m} \ell$ water samples taken from 47 water sites within 2 villages in Nyabushozi County in the Mbarara District of south-western Uganda. The water samples were plated onto EC $3 \mathrm{M}^{\mathrm{TM}}$ Petrifilm ${ }^{\mathrm{TM}}$ according to the manufacturer's instructions and incubated at $37^{\circ} \mathrm{C}$ for $24 \mathrm{~h}$. Forty-two of the 47 water sites were positive for enteric bacteria. Random isolates were taken from the Petrifilms and biochemically identified and then representative isolates were verified by sequencing the variable region of their 16S rRNA gene as previously reported (Pearson et al., 2008). Many of the 16S rRNA gene sequences obtained allowed identification to the genus but not species level. From the initial study, 52 genetically distinct archived bacteria were available for further study. These included: 2 Citrobacter spp., 20 E. coli, 7 Enterobacter spp., 5 Klebsiella spp., 3 Morganella morganii, 2 Proteus spp., 3 Providencia rettgeri, 4 Pseudomonas spp., 4 Salmonella spp., and 2 Serratia odorifera. Because E. coli $0157: \mathrm{H} 7$ had previously been reported in the area (Majalija et al., 2008), we cultured the 20 E. coli isolates on SorbitolMacConkey medium-SMAC (Remel, Inc., Lenexa, KS, USA; March and Ratnam, 1986). No growth was observed indicating that they were not $E$. coli $0157: \mathrm{H} 7$. Two laboratory strains, $E$. coli $\mathrm{HB} 101$ and $E$. coli $\mathrm{DH} 5 \alpha$ were used as recipients in conjugation experiments. 


\begin{tabular}{|c|c|c|c|c|}
\hline \multicolumn{5}{|c|}{$\begin{array}{c}\text { TABLE } 1 \\
\text { List of oligonucleotide primers used in this study }\end{array}$} \\
\hline $\begin{array}{l}\text { Resistance } \\
\text { gene }\end{array}$ & $\begin{array}{l}\text { Primer } \\
\text { name }\end{array}$ & Sequence $\left(5^{\prime} \rightarrow 3^{\prime}\right)$ & $\begin{array}{l}\text { Amplicon } \\
\text { size (bp) }\end{array}$ & Reference \\
\hline \multirow[t]{3}{*}{$\operatorname{ere}(\mathrm{A})$} & ereA-fw & TCA CTG GCT AGA GCT AGT CTT & 993 & Soge et al., 2006a \\
\hline & ereA-rv & CAT TCG CTT TGC TTC CAT GGG & & \\
\hline & ereA-int & GAG TTG GAA ACG GCT CAG CAG GAG & & \\
\hline \multirow[t]{3}{*}{$\operatorname{ere}(\mathrm{B})$} & ereB-fw & TTG GAG ATA CCC GAG TTG TAG & 982 & Soge et al., 2006a \\
\hline & ereB-rv & GCT TTC TCG ACA GAA CCT TCA & & \\
\hline & ereB-int & CAG AAA TGG AGG TTC ATA CTT ACC & & \\
\hline \multirow[t]{3}{*}{$\operatorname{erm}(\mathrm{B})$} & ermB-fw & GAA AAG GTA CTC AAC CAA ATA & 639 & Ojo et al., 2004 \\
\hline & ermB-rv & AGT AAC GGT ACT TAA ATT GTT TAC & & \\
\hline & ermB-int & AGC CAT GCG TCT GAC ATC TAT & & \\
\hline \multirow[t]{3}{*}{$m p h(\mathrm{~A})$} & $m p h \mathrm{~A}-\mathrm{fw}$ & GAT ACC TCC CAA CTG TAC GCA & 850 & Soge et al., $2006 \mathrm{a}$ \\
\hline & $m p h$ A-rv & CGA GGT ACT CTT CGT TAC CC & & \\
\hline & $m p h$ A-int & GCT GGC AAT GCT CAA GAA TCG & & \\
\hline \multirow[t]{3}{*}{$m p h(\mathrm{~B})$} & $m p h \mathrm{~B}-\mathrm{fw}$ & TTA AAC AAG TAA TCG AGA TAG C & 889 & Ojo et al., 2004 \\
\hline & $m p h \mathrm{~B}-\mathrm{rv}$ & CCT TGT ACT TCC AAT GCT T C & & \\
\hline & $m p h \mathrm{~B}$-int & GCG TAT GGA TGC AGT AAG AGC & & \\
\hline \multirow[t]{3}{*}{$m p h(\mathrm{C})$} & MPHC1 & ATG ACT CGA CAT AAT GAA ATT ATT & 900 & Ojo et al., 2004 \\
\hline & MPHC2 & CTA CTC TTT CAT ACC TAA CTC & & \\
\hline & MPHC int & GCT GAA ACA CTC GTA GAT TTA CAC & & \\
\hline \multirow[t]{3}{*}{$m p h(\mathrm{D})$} & $m p h \mathrm{D}-\mathrm{fw}$ & AGC CAA TTG CTA CAT GCG CTC T & 756 & Soge et al., 2006a \\
\hline & $m p h \mathrm{D}-\mathrm{rv}$ & GGG TTT ACG AGC CAA GCA AGA A & & \\
\hline & $m p h \mathrm{D}$-int & TCA TTC GGC AAC AGC CTG TGC A & & \\
\hline \multirow[t]{3}{*}{$m e f(\mathrm{~A})$} & MefF & TGT GCA TAT TTC TAT TAC G & 324 & Ojo et al., 2004 \\
\hline & MefR & CCA ATT GGC ATA GCA AG & & \\
\hline & MefInt & GCT GTG CAA TAA TGG GGC & & \\
\hline \multirow[t]{3}{*}{ int1 } & IntI-fw & CAA GGT TCT GGA CCA GTT GC & 907 & Soge et al., 2006a \\
\hline & IntI-rv & CAG CAC ATG CGT GTA AAT CA & & \\
\hline & IntI1-int & CAG GCT TAT GTC CAC TGG GT & & \\
\hline \multirow[t]{3}{*}{ sull } & sull-fw & TCA CCG AGG ACT CCT TCT TC & 804 & Soge et al., 2006a \\
\hline & sull-rv & GAT CTA ACC CTC GGT CTC TGG & & \\
\hline & Sull-int & GCT CTT AGA CGC CCT GTC CG & & \\
\hline \multirow[t]{3}{*}{$\operatorname{tet}(\mathrm{A})$} & A1 & CGA GCC ATT CGC GAG AGC & 2027 & Miranda et al., 2003 \\
\hline & $\mathrm{A} 2$ & CGA ABC AAG CAG GAC CAT G & & \\
\hline & A3 & GCC TCC TGC GCG ATC TGG & & \\
\hline \multirow[t]{2}{*}{$\operatorname{tet}(\mathrm{B})$} & $\mathrm{BF}$ & CAG TGC TGT TGT TGT CAT TAA & 571 & Miranda et al., 2003 \\
\hline & BR & GCT TGG AAT ACT GAG TGT AA & & \\
\hline \multirow[t]{2}{*}{$\operatorname{tet}(\mathrm{C})$} & $\mathrm{CF}$ & TTG CAT GCA CCA TTC CTT GCG & 522 & Miranda et al., 2003 \\
\hline & $\mathrm{CR}$ & ATG GTC GTC ATC TAC CTG CC & & \\
\hline \multirow[t]{2}{*}{$\operatorname{tet}(\mathrm{D})$} & DF & GGA TAT CTC ACC GCA TCT GC & 436 & Miranda et al., 2003 \\
\hline & DR & CAT CCA TCC GGA AGT GAT AGC & & \\
\hline \multirow[t]{2}{*}{$\operatorname{tet}(\mathrm{E})$} & $\mathrm{EF}$ & TCC ATA CGC GAG ATG ATC TCC & 442 & Miranda et al., 2003 \\
\hline & ER & CGA TTA CAG CTG TCA GGT GGG & & \\
\hline \multirow[t]{2}{*}{$\operatorname{tet}(\mathrm{G})$} & GF & GCT GGA TGA TGC ATT GCG CG & 554 & This study \\
\hline & GR & ATG GTC TGC GTA GTA TTG GC & & \\
\hline \multirow[t]{2}{*}{$\operatorname{tet}(\mathrm{M} / \mathrm{O} / \mathrm{S})$} & M4 & GAA GCC CAG AAA GGA TTY GGT & 686 & Miranda et al., 2003 \\
\hline & M6 & GTT TAT CAC GGA AGY GCW A & & \\
\hline$b l a_{\mathrm{TEM}-1} *$ & TEM INT & AGC CCT CCC GTA TCG TAG TT & & Soge et al., 2006b \\
\hline $\operatorname{bla}_{\mathrm{SHV}-1} *$ & SHV INT & ATT TAT CTG CGG GAT ACC CC & & Soge et al., 2006b \\
\hline
\end{tabular}

\section{Antibiotic susceptibility}

Antimicrobial susceptibilities were performed using disc diffusion on Mueller-Hinton agar (Remel, Inc., Lenexa, KS, USA) according to the CLSI guidelines (CLSI, 2003a). E. coli ATCC 25922 was used as a control. The antibiotic disks included ampicillin $(10 \mu \mathrm{g})$, cefotaxime $(30 \mu \mathrm{g})$, ceftazidime $(30 \mu \mathrm{g})$, chloramphenicol $(30 \mu \mathrm{g})$, kanamycin $(30 \mu \mathrm{g})$, tetracycline $(30 \mu \mathrm{g})$, trimethoprim/sulfamethoxazole $(25 \mu \mathrm{g})$ (Remel, Inc., Lenexa, KS, USA). In addition, minimum inhibitory concentrations (MICs) were performed using an agar dilution method according to the CLSI guidelines (CLSI, 2003b) for ceftazidime, cefotaxime, aztreonam, piperacillin, cefepime, erythromycin, and imipenem for 26 ampicillin resistant $\left(\mathrm{Ap}^{\mathrm{r}}\right)$ isolates.

\section{Detection of antibiotic resistance genes}

Polymerase chain reaction (PCR) assays were used for the detection of tetracycline resistance genes [tet $(\mathrm{A}), \operatorname{tet}(\mathrm{B}), \operatorname{tet}(\mathrm{C})$, $\operatorname{tet}(\mathrm{D}), \operatorname{tet}(\mathrm{E}), \operatorname{tet}(\mathrm{G})$ and $\operatorname{tet}(\mathrm{M})]$; macrolide or combinations of 
TABLE 2

Phenotypic and genotypic characteristics of bacterial isolates from rural Ugandan water sources

\begin{tabular}{|c|c|c|c|c|}
\hline \multirow[t]{2}{*}{ Strain } & \multirow{2}{*}{$\begin{array}{l}\text { Resistance } \\
\text { phenotype }^{a}\end{array}$} & \multicolumn{3}{|c|}{ Resistance genotype } \\
\hline & & tet genes ${ }^{b}$ & MLS genes $^{c}$ & Other resistance gene(s) \\
\hline E. coli 301 & Ap, Tc, SXT, Erm & $\operatorname{tet}(\mathrm{A})$ & $m e f(\mathrm{~A})$ & $b_{l a}$ \\
\hline E. coli 302 & Ap, Tc, SXT & $\operatorname{tet}(\mathrm{A}), \operatorname{tet}(\mathrm{C}), \operatorname{tet}(\mathrm{G})$ & - & sull, bla $a_{\mathrm{TEM}-1,}$ bla $a_{\mathrm{SHV}-1}$ \\
\hline E. coli 304 & Ap, Tc, SXT, Erm & $\operatorname{tet}(\mathrm{A}), \operatorname{tet}(\mathrm{C}), \operatorname{tet}(\mathrm{G})$ & $\operatorname{erm}(\mathrm{B})$ & sull, intIl, bla ${ }_{\mathrm{TEM}-1}$ \\
\hline E. coli 387 & Ap, Tc, Erm & $\operatorname{tet}(\mathrm{A}), \operatorname{tet}(\mathrm{C}), \operatorname{tet}(\mathrm{G})$ & $m e f(\mathrm{~A})$ & sull, bla $a_{\mathrm{TEM}-1}$ \\
\hline E. coli 270 & Ap, Tc, Cm, Erm & $\operatorname{tet}(\mathrm{A})$ & $m e f(\mathrm{~A})$ & sull, intIl, bla ${ }_{\mathrm{TEM}-1}$ \\
\hline E. coli 317 & Ap & - & - & $b l a_{\mathrm{TEM}-1}$ \\
\hline Citrobacter sp. 283 & Ap, Tc, Erm & tet(D) & - & $b l a_{\mathrm{TEM}-1}$ \\
\hline Citrobacter sp. 104 & $\mathrm{Kn}, \mathrm{Ap}, \mathrm{Erm}$ & - & - & $b l a_{\mathrm{TEM}-1}$ \\
\hline Enterobacter sp. 267 & Ap & - & - & sull, intIl, bla $a_{\mathrm{TEM}-1,}$ \\
\hline Enterobacter sp. 275 & Ap & - & - & $b l a_{\mathrm{TEM}-1}$ \\
\hline Enterobacter sp. 307 & Ap, Erm & - & $\operatorname{erm}(\mathrm{B})$ & - \\
\hline E. cloacae 325 & Ap, Erm & - & $\operatorname{erm}(\mathrm{B}), \operatorname{mef}(\mathrm{A})$ & $b l a_{\mathrm{TEM}-1}$ \\
\hline E. endosymbiont 173 & Ap, Erm & - & $\operatorname{erm}(\mathrm{B})$ & sull, bla \\
\hline Klebsiella sp. 328 & Ap & - & - & $b l a_{\mathrm{SHV}-1}$ \\
\hline K. pneumoniae 426 & Ap & - & - & sull, bla $a_{\mathrm{TEM}-1}$ bla $a_{\mathrm{SHV}-1}$ \\
\hline M. morganii 261 & $\mathrm{Ap}, \mathrm{Tc}$ & tet $(\mathrm{M})$ & - & $b l a_{\mathrm{TEM}-1}$ \\
\hline M. morganii 390 & Ap, Erm & - & $\operatorname{erm}(\mathrm{B})$ & $b l a_{\mathrm{TEM}-1,} b l a_{\mathrm{SHV}-1}$ \\
\hline M. morganii 421 & Ap & - & - & $b^{\prime} a_{\mathrm{TEM}-1}$ \\
\hline Proteus sp. 421 & Ap, Tc & $\operatorname{tet}(\mathrm{A}), \operatorname{tet}(\mathrm{M})$ & - & - \\
\hline Proteus sp. 222 & Ap, Tc & $\operatorname{tet}(\mathrm{G})$ & - & $b l a_{\mathrm{TEM}-1}$ \\
\hline Providencia rettgeri 3 & $\mathrm{Tc}$ & tet(B) & - & - \\
\hline P. rettgeri 318 & Ap, Tc & $\operatorname{tet}(\mathrm{A})$ & - & $b l a_{\mathrm{TEM}-1}$ \\
\hline S. paratyphi 38 & Ap & - & - & bla $a_{\text {TEM-1 }}$ \\
\hline Salmonella sp. 223 & Ap, Tc, Erm & $\operatorname{tet}(\mathrm{C}), \operatorname{tet}(\mathrm{G})$ & $m e f(\mathrm{~A})$ & bla $_{\mathrm{TEM}-1}$ \\
\hline Salmonella sp. 276 & Ap & - & - & $b l a_{\mathrm{TEM}-1}$ \\
\hline Serratia odorifera 394 & Ap & - & - & sull, intIl, bla $a_{\mathrm{TEM}-1}$ \\
\hline
\end{tabular}

${ }^{a}$ Ap, ampicillin; Tc, tetracycline; Erm, erythromycin; Kn, kanamycin; SXT, trimethoprim/sulfamethoxazole. All isolates were susceptible to CAZ,

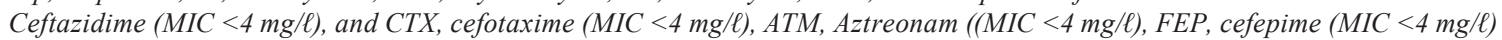

${ }^{b}$ None of the isolates carried the tet $(E)$ gene

${ }^{c}$ All isolates were negative for $m p h(A), m p h(B), m p h(C), m p h(D)$, ere $(A)$ and ere $(B)$

macrolide-lincosamide-streptogramin [MLS] genes [erm(B), $m e f(\mathrm{~A}), \operatorname{ere}(\mathrm{A}), \operatorname{ere}(\mathrm{B}), m p h(\mathrm{~A}), m p h(\mathrm{~B}), m p h(\mathrm{C})$, and $m p h(\mathrm{D})]$; the intI1 integrase for Class 1 integron and sull gene coding for sulphonamide resistance were performed as previously described (Miranda et al., 2003; Soge et al., 2006a). Positive and negative controls were used for each PCR assay. The PCR products were verified by DNA-DNA hybridisation with internal probes as previously described (Soge et al., 2006a). The ampicillin resistance genes $b l a_{\mathrm{TEM}}$ and $b l a_{\mathrm{SHV}}$ were identified as previously described (Soge et al., 2006b). The PCR primers and probes are listed in Table 1.

\section{Plasmids isolation}

Plasmid DNA was extracted using a modified alkaline lysis procedure and electrophoresed through $0.7 \%$ agarose gel with the E. coli V517 (58 kb); R1 (100 kb) and R478 (274.5 kb) used as markers for plasmid size estimation as previously described (Soge et al., 2006a).

\section{Conjugal gene transfer}

Mating experiments were carried out using E. coli HB101 and/or E. coli $\mathrm{DH} 5 \alpha$ as recipients. Both isolates have previously been selected for chromosomal resistance to streptomycin $(500 \mathrm{mg} / \ell)$, fusidic acid $(25 \mathrm{mg} / \ell)$, nalidixic acid $(25 \mathrm{mg} / \ell)$, and rifampicin $(25 \mathrm{mg} / \ell)\left[\mathrm{Strep}^{\mathrm{r}}, \mathrm{Fus}^{\mathrm{r}}, \mathrm{Rif}^{\mathrm{r}}\right.$, and Nal$\left.{ }^{\mathrm{r}}\right]$ as recipients (Soge et al., 2006a). E. coli 302, E. coli $304\left(\mathrm{Ap}^{\mathrm{r}}, \mathrm{Tc}^{\mathrm{r}}, \mathrm{SXT}^{\mathrm{r}}\right)$, E. coli 387 $\left(\mathrm{Ap}^{\mathrm{r}}, \mathrm{Tc}^{\mathrm{r}}\right.$, Erm $\left.^{\mathrm{r}}\right)$, Enterobacter cloacae 325, Morganella morganii 390, Serratia odorifera 394, Citrobacter sp. 283 and Proteus sp. 222 were used as donors. Transconjugants were selected on one of the following; Luria-Bertani agar (Difco Laboratories, Kansas, MO, USA) supplemented with rifampicin $(25 \mathrm{mg} / \ell)$ plus ampicillin $(50 \mathrm{mg} / \ell)$, streptomycin $(250 \mathrm{mg} / \ell)$ plus ampicillin $(50 \mathrm{mg} / \ell)$, rifampicin $(25 \mathrm{mg} / \ell)$ plus tetracycline $(20 \mathrm{mg} / \ell)$, rifampicin $(25 \mathrm{mg} / \ell)$ plus erythromycin $(128 \mathrm{mg} / \ell)]$ as described previously (Soge et al., 2006a). Mating experiments were done with a ratio of 1:1 of the donor to recipient with $E$. coli as the parental strains and ratios of 1:10, 1:50, 1:100, and 1:200 donor to recipient with Enterobacter cloacae, Morganella morganii, Serratia odorifera, Citrobacter sp. and Proteus sp. parental strains. Transconjugants were confirmed biochemically and their antibiotic resistance genes verified by PCR assays followed by DNADNA hybridisation of the PCR products using radio-labelled internal probes as previously described (Soge et al., 2006a).

\section{Results}

\section{Antibiotic susceptibility and antibiotic resistance genes}

Of the 52 Gram-negative isolates examined, 26 were susceptible to all antibiotics and 26 isolates were resistant to $\geq 1$ of the antibiotics examined, with 14 isolates exhibiting multidrug 
TABLE 3

Conjugal transfer of resistance genes in Ugandan isolates

\begin{tabular}{|c|c|c|c|c|c|}
\hline Donor & Number of plasmid & Recipient & Frequency $^{a}$ & $\begin{array}{l}\text { Number of } \\
\text { plasmid } \\
\text { transferred }\end{array}$ & Genes transferred \\
\hline E. coli 302 & $2(65 \mathrm{~kb}, 125 \mathrm{~kb})$ & DH5 $\alpha$ & $8.38 \times 10^{-5}$ & $1(65 \mathrm{~kb})$ & $\operatorname{tet}(\mathrm{A}), \operatorname{tet}(\mathrm{C}), \operatorname{tet}(\mathrm{G})$, sull, bla \\
\hline E. coli 304 & $2(58 \mathrm{~kb}, 95 \mathrm{~kb})$ & DH5 $\alpha$ & $1.37 \times 10^{-6}$ & $1(58 \mathrm{~kb})$ & $\operatorname{tet}(\mathrm{A}), \operatorname{tet}(\mathrm{C})$, tet $(\mathrm{G})$, sull bla \\
\hline E. coli 387 & $2(75 \mathrm{~kb}, 110 \mathrm{~kb})$ & HB101 & $4.17 \times 10^{-6}$ & $1(75 \mathrm{~kb})$ & tet(A), sull, bla \\
\hline
\end{tabular}

${ }^{a}$ Transconjugants/number of recipient bacteria. All transconjugants were ampicillin and tetracycline resistant; $58 \mathrm{~kb}$, $65 \mathrm{~kb}$ and $75 \mathrm{~kb}$ plasmids transferred in E. coli 304, E. coli 302, and E. coli 387 respectively

No detectable transconjugants were obtained (transfer frequency $<10^{-9}$ ) for E. cloacae 325, M. morganii 390, S. odorifera 394, Citrobacter sp. 283 and Proteus sp. 222

resistance. $\mathrm{Ap}^{\mathrm{r}}$ was found in 25 of the 26 antibiotic resistant isolates including 6 E. coli, 5 Enterobacter spp., 1 Salmonella paratyphi, 2 Salmonella spp., 2 Klebsiella spp., 2 Citrobacter spp., 2 Proteus spp., 3 M. morganii, one each of $P$. rettgeri and S. odorifera. All $\mathrm{Ap}^{\mathrm{r}}$ isolates were susceptible to ceftazidime, cefotaxime, aztreonam, cefepime with MIC $<4 \mathrm{mg} / \ell$ for all 4 drugs tested suggesting that they did not carry genes coding for extended- $\beta$-lactamases. Nineteen of $\mathrm{Ap}^{\mathrm{r}}$ isolates carried a bla $_{\text {TEM }}$ gene, 1 E. coli, Klebsiella sp. and M. morganii carried both $b l a_{\mathrm{TEM}}$ and $b l a_{\mathrm{SHV}}$ genes, and 1 Klebsiella sp. carried a bla $a_{\mathrm{SHV}}$ gene (Table 2). Two isolates did not carry either the $b l a_{\text {TEM }}$, and $b l a_{\mathrm{SHV}}$ or $b l a_{C T X-M}$ genes.

Twelve isolates were tetracycline resistant $\left(\mathrm{Tc}^{\mathrm{r}}\right)$ with 7 isolates carrying a single tet gene. Three isolates carried the tet(A) gene and 1 isolate each with the $\operatorname{tet}(\mathrm{B}), \operatorname{tet}(\mathrm{D}), \operatorname{tet}(\mathrm{G})$ or the tet $(\mathrm{M})$ gene. The remaining 5 isolates carried multiple tet genes and included 3 isolates with the $\operatorname{tet}(\mathrm{A}), \operatorname{tet}(\mathrm{C})$, and $\operatorname{tet}(\mathrm{G})$ genes, 1 isolate with both the $\operatorname{tet}(\mathrm{A})$ and $\operatorname{tet}(\mathrm{M})$ genes, and 1 isolate with both the $\operatorname{tet}(\mathrm{C})$ and $\operatorname{tet}(\mathrm{G})$ genes. Eleven isolates had erythromycin MIC $>128 \mathrm{mg} / \ell$ and 5 of these isolates carried macrolide $[m e f(\mathrm{~A})]$ and/or macrolide-lincosamide-streptogramin B [erm(B)] resistance genes, while all 11 isolates were negative for $m p h(\mathrm{~A}), m p h(\mathrm{~B}), m p h(\mathrm{C}), m p h(\mathrm{D}), \operatorname{ere}(\mathrm{A})$ and $\operatorname{ere}(\mathrm{B})$. Eight isolates carried the sull gene and 4 of these isolates also carried the intl gene suggestive of an integron. One isolate was chloramphenicol resistant though the resistance gene was not determined.

\section{Plasmids}

Thirteen isolates, including 5 E. coli, 3 Enterobacter spp., 1 Klebsiella sp., 1 Proteus sp., 1 Providencia rettgeri sp., and 2 Salmonella spp., carried 1 to 3 plasmids with molecular weights of 3 to $150 \mathrm{~kb}$ (data not shown) while the remaining 13 antibiotic resistant isolates, had no detectable plasmid DNA using the single plasmid extraction method.

\section{Conjugation transfer experiments}

Three E. coli; E. coli 302, E. coli 304 , and E. coli 387, along with E. cloacae 325, M. morganii 390, S. odorifera 394, and Citrobacter sp. 283 and Proteus sp. 222 were used as donors with recipient $E$. coli $\mathrm{HB} 101$ and/or $E$. coli $\mathrm{DH} 5 \alpha$. All 3 E. coli donors transferred $\mathrm{Ap}^{\mathrm{r}}$ and $\mathrm{Tc}^{\mathrm{r}}$ at a frequency ranging from $10^{-5}$ to $10^{-6}$ /recipient. Enterobacter cloacae 325 carrying 2 large plasmids (>58 kb) and other donors M. morganii 390, S. odorifera 394, and Citrobacter sp. 283 and Proteus sp. 222, which had no detectable plasmid gave no transconjugants (transfer frequency $<10^{-9}$ ) using 4 different ratio combinations of donor to recipient (1:10, $1: 50,1: 100,1: 1200)$ with both HB101 and DH5 $\alpha$ as recipients in repeated experiments. All the transconjugants from the E. coli to $E$. coli mating were $\mathrm{Ap}^{\mathrm{r}} \mathrm{Tc}^{\mathrm{r}}$ and carried a single large plasmid of molecular weights $58 \mathrm{~kb}, 65 \mathrm{~kb}, 75 \mathrm{~kb}$ for E. coli $304, E$. coli 302 and E. coli 387 respectively (Table 3 ).

All transconjugants carried the $b l a_{\text {TEM }}$ conferring resistance to $\mathrm{Ap}^{\mathrm{r}}$, the sull gene but differed in the tet genes that were transferred to the transconjugants. E. coli 302, E. coli 304 donors transferred tet $(\mathrm{A}), \operatorname{tet}(\mathrm{C})$ and $\operatorname{tet}(\mathrm{G})$ genes, while $E$. coli 387 donor transferred only the tet(A) gene.

\section{Discussion}

In the current study, 26 out of 52 water-borne Ugandan Gramnegative bacteria were antibiotic resistant and 14 were multidrug resistant. None of the isolates carried extended-spectrum $\beta$-lactamases, and 4 isolates carried genes consistent with a Class 1 integron. $\mathrm{Ap}^{\mathrm{r}}$ was the most common resistance phenotype among the Ugandan isolates. In the E. coli isolates, $A p^{r}$ was associated with conjugative plasmids $[58,65,75 \mathrm{~kb}]$, while the other Gram-negative isolates appeared to have chromosomally mediated $\mathrm{Ap}^{\mathrm{r}}$ genes, which we were unable to conjugally transfer in the study. None of the antibiotic-resistant isolates were resistant to cefotaxime and ceftazidime, while clinical human African enteric bacteria are usually resistant to cephalosporins and often carry multiple $\beta$-lactamases encoded by bla $a_{\text {СтХ-М }}$, $b l a_{\mathrm{CMY}}$, and $b l a_{\mathrm{VIM}}$ type genes in addition to $b l a_{\mathrm{SHV}}$ and $b l a_{\mathrm{TEM}-\mathrm{I}}$ (Frank et al., 2006; Gray et al., 2006; Ktari et al., 2006; Soge et al., 2006b). Two isolates from the current Ugandan study, Proteus 421 and Enterobacter 307, were Ap ${ }^{\mathrm{r}}$ but did not carry either $b l a_{\text {SHV }}, b l a_{\text {TEM-1 }}, b l a_{\text {CTX-M }}$ genes. Similarly, 2 Citrobacter spp. 283 and 104 had erythromycin MICs $>128 \mathrm{mg} / \ell$ but did not carry any of the 8 common MLS genes examined. One SXT $E$. coli did not carry the sull gene while all $12 \mathrm{Tc}^{\mathrm{r}}$ isolates carried previously characterised tet genes.

Three of the 8 isolates used as donors were able to conjugally transfer antibiotic resistance to the recipients. The resulting transconjugants carried a single plasmid, which carried 1-3 tet genes, sull and bla $_{\mathrm{TEM}-1}$ genes. The $b l a_{\mathrm{SHV}-1}$ was not associated with these conjugative plasmids and was not transferred in the experiments. In contrast, the remaining 5 donor isolates did not generate transconjugants.

In one Nigerian study, small differences in antibiotic susceptibility between the clinical bacteria and bacteria isolated from soil, industrial effluent, food and drinking water were found (Lateef et al., 2005), suggesting the possibility that clinical and water-borne bacteria may have the same level of antibiotic resistance. Little work on the level of antibiotic carriage in Ugandan Gram-negative bacteria is available; however, in a 1998 paper, the authors reported that $92 \%$ of the endemic Shigella isolated in Mbarara, Uganda were resistant to 
cotrimoxazole and 58\% were resistant to ampicillin (Legros et al., 1998). Previous studies on water enteric bacteria from other African countries also showed higher rates of antibiotic resistance than those found in this study. For instance, two separate Nigerian studies have found high levels of antibiotic-resistant (93 to 94\%) water-borne enteric bacteria, isolated from communal well water, and from the lower Niger Delta River (Ibiebele et al., 1989; Ogan et al., 1993). Lin et al. (2004) characterised 113 enteric bacteria, including E. coli, Klebsiella sp., C. freundii, Enterobacter spp., S. marcesens, isolated from the Mhlathuze River in South Africa and found that $94.7 \%$ of these bacteria were resistant to $\geq 1$ antibiotic and $75.2 \%$ of the isolates were multidrug resistant. The low level of Class 1 integrons found in the Ugandan isolates differs from recent studies of Class 1 integrons where $12 \%$ of the $E$. coli isolated from a remote community of Guarani Indians in Bolivia, and $40 \%$ of 100 multi-drug resistant Gram-negative bacteria, from the River Torsa, India, carried Class 1 integrons (Pallecchi et al., 2007; Mukherjee and Chakraborty, 2006).

Unregulated use of antibiotics in agriculture, animal husbandry, and medical therapy has been a major influence in Africa and is often cited as a major reason why there is high prevalence of multidrug resistant bacteria (Okeke et al., 2007). Why the Ugandan water bacteria in this study differ from other studies from remote areas in Africa is intriguing. However, this study does illustrate that the level of antibiotic resistance found in water-borne Gram-negative bacteria can vary among Gram-negative bacteria isolated from various remote parts of the world where exposure to western medicine and antibiotics is minimal.

\section{Acknowledgements}

This study was presented in part at the $108^{\text {th }}$ American Society for Microbiology General Meeting, June 1-5, 2008, Boston Massachusetts (Abstract A-115).

\section{References}

CLINICAL AND LABORATORY STANDARDS INSTITUTE (CLSI) (2003a) Performance Standards for Antimicrobial Disk Susceptibility Tests ( $8^{\text {the }}$ dn.): Approved Standard M2-A8. CLSI, Wayne, PA, USA.

CLINICAL AND LABORATORY STANDARDS INSTITUTE (CLSI) (2003b) Methods for Dilution Antimicrobial Susceptibility Tests for Bacteria that Grow Aerobically (6 ${ }^{\text {th }}$ edn.): Approved Standard M7-A6. CLSI, Wayne, PA, USA.

FRANK T, ALERT G, GAUTIER V, TALARMIN A and BERCION R (2006) Extended-spectrum beta-lactamase-producing Enterobacteriaceae, Central African Republic. Emerg. Infect. Dis. 12 863-865.

GRAY KJ, WILSON LK, PHIRI A, CORKILL JE, FRENCH N and HART CA (2006) Identification and characterization of ceftriaxone resistance and extended-spectrum beta-lactamases in Malawian bacteraemic Enterobacteriaceae. J. Antimicrob. Chemother. 57 661665

IBIEBELE DD and SOKARI TG (1989) Occurrence of drug-resistant bacteria in communal well water around Port Harcourt, Nigeria. Epidemiol. Infect. 103 193-202.
KTARI S, ALERT G, MNIF B, GAUTIER V, MAHJOUBI F, BEN JM, BOUAZIZ M and HAMMAMI A (2006) Emergence of multidrugresistant Klebsiella pneumoniae isolates producing VIM-4 metallobeta-lactamase, CTX-M-15 extended-spectrum beta-lactamase, and CMY-4 AmpC beta-lactamase in a Tunisian university hospital. Antimicrob. Agents Chemother. 12 4198-4201.

LATEEF A, OLOKE JK, and GUEGUIMKANA EB (2005) The prevalence of bacterial resistance in clinical, food, water and some environmental samples in Southwest Nigeria. Environ. Monit. Assess. 100 59-69.

LEGROS D, OCHOLA D, LWANGA N, and GUMA G (1998) Antibiotic sensitivity of endemic Shigella in Mbarara, Uganda. East Afr. Med. J. 75 160-161.

LIN J, BIYELA, PT and PUCKREE T (2004) Antibiotic resistance profiles of environmental isolates from Mhlathuze River, KwaZuluNatal (RSA). Water SA 30 (1) 23-28 http://www.wrc.org.za/archives/ watersa\%20archive/2004/Jan-04/4.pdf.

MAJALIJA S, SEGAL H, EJOBI F and ELISH GB (2008) Shiga toxin gene-containing Escherichia coli from cattle and diarrheic children in the pastoral systems of southwestern Uganda. J. Clin. Microbiol. 46 352-354.

MARCH SB and RATNAM S (1986) Sorbitol-MacConkey medium for detection of Escherichia coli O157:H7 associated with hemorrhagic colitis. J. Clin. Microbiol. 23 869-872.

MIRANDA CD, KEHRENBERG C, ULEP C, SCHWARZ S and ROBERTS MC (2003) Diversity of tetracycline resistance genes in bacteria from Chilean salmon farms. Antimicrob. Agents Chemother. 47 883-888.

MUKHERJEE S and CHAKRABORTY R (2006) Incidence of class 1 integrons in multiple antibiotic-resistant Gram-negative copiotrophic bacteria from the River Torsa in India. Res. Microbiol. 157 220-226.

OGAN MT and NWIIKA DE (1993) Studies on the ecology of aquatic bacteria of the lower Niger Delta: multiple antibiotic resistance among the standard plate count organisms. J. Appl. Bacteriol. 74 595-602.

OJO KK, ULEP C, VAN KIRK N, LUIS H, BERNARDO M, LEITAO $\mathrm{J}$ and ROBERTS MC (2004) The mef(A) Gene predominates among seven macrolide resistance genes identified in Gram-negative strains representing 13 genera, isolated from healthy Portuguese children. Antimicrob. Agents Chemother. 48 3451-3456.

OKEKE IN, ABODERIN OA, BYARUGABA DK, OJO KK and OPINTAN JA (2007) Growing problem of multidrug-resistant enteric pathogens in Africa. Emerg. Infect. Dis. 13 1640-1646.

PALLECCHI L, LUCCHETTI C, BARTOLONI A, BARTALESI F, MANTELLA A, GAMBOA H, CARATTOLI A, PARADISI F and ROSSOLINI GM (2007) Population structure and resistance genes in antibiotic-resistant bacteria from a remote community with minimal antibiotic exposure. Antimicrob. Agents Chemother. 51 11791184.

PEARSON AL, ROBERTS MC, SOGE OO, IVANOVA I, MAYER JD and MESCHKE JS (2008) Utility of EC $3 M^{T M}$ petrifilms TM and sanitary surveys for source water assessment in south-western Uganda. Water SA 34 (2) 279-283. http://www.wrc.org.za/downloads/watersa/2008/April/2227.pd

SOGE OO, ADENIYI BA and ROBERTS MC (2006a) New antibiotic resistance genes associated with CTX-M plasmids from uropathogenic Nigerian Klebsiella pneumoniae. J. Antimicrob. Chemother. 58 1048-1053.

SOGE OO, QUEENAN AM, OJO KK, ADENIYI BA and ROBERTS MC (2006b) CTX-M-15 extended-spectrum beta-lactamase from Nigerian Klebsiella pneumoniae. J. Antimicrob. Chemother. 57 24-30. 
Available on website http://www.wrc.org.za ISSN 0378-4738 = Water SA Vol. 35 No. 3 April 2009 ISSN 1816-7950 = Water SA (on-line) 